\title{
Evapotranspiration and crop coefficients in two irrigated wheat cultivars
}

\author{
Tonny J. A. da Silva ${ }^{1}$, Edna M. Bonfim-Silva ${ }^{1}$, William Fenner ${ }^{2}$, Thiago F. Duarte ${ }^{1}$, Jefferson V. José ${ }^{1} \&$ \\ Thiago H. F. M. Castañon ${ }^{2}$
} ${ }^{1}$ Universidade Federal de Rondonópolis/Instituto de Ciências Agrárias e Tecnológicas, Rondonópolis, MT, Brasil. E-mail: tonnyjasilva@hotmail.com
- ORCID: 0000-0002-6978-7652; embonfim@hotmail.com (Corresponding author) - ORCID: 0000-0003-1989-8431; thiagof.duarte@hotmail.com -
ORCID: 0000-0001-6504-8089; jfvieira@usp.br - ORCID: 0000-0003-1384-0888
${ }^{2}$ Universidade Federal de Mato Grosso/Faculdade de Agronomia e Zootecnia, Cuiabá, MT, Brasil. E-mail: fennerwilliam@gmail.com - ORCID: 0000-
0002-3463-9457; thiagocastanon@live.com - ORCID: 0000-0003-2186-0678

\begin{abstract}
In the state of Mato Grosso, Brazil, wheat is an alternative to the current production system, mainly in irrigated crops, with new cultivars improved for this environment and system. The objective was to determine the evapotranspiration of the irrigated wheat crop and the dual coefficients of cultivars for the Brazilian Midwest. The experiment was conducted in the field using 12 weighing lysimeters and minilysimeters, filled by soil monoliths. The wheat cultivars BRS-254 and BRS-394 were used in the first and second years, respectively. Reference evapotranspiration was obtained by the Penman-Monteith equation and crop evapotranspiration by the mass difference in the lysimeters. Basal crop coefficient and soil water evaporation coefficient were determined according to the crop development stages in both years of cultivation. The mean ETc and ETo values were 3.87, $3.49 \mathrm{~mm} \mathrm{~d}^{-1}$ and 4.10 and $3.23 \mathrm{~mm} \mathrm{~d}^{-1}$, respectively, in the first and second cultivation cycles, with higher values of ETc recorded in the reproductive stages of the crop, flowering and grain filling. The basal crop coefficients and soil water evaporation coefficients estimated by weighing lysimeters composed of soil monoliths are: $\mathrm{Kcb}-0.42,0.78,0.94,0.74$ and 0.47 and $\mathrm{Ke}-0.72,0.52,0.39,0.58$ and 0.13 for the cultivar BRS-254, and $\mathrm{Kcb}-0.28,0.27,0.65,0.98$ and 0.66 and $\mathrm{Ke}-1.04,0.96,0.65,0.34$ and 0.51 for the cultivar BRS-394, at the stages of emergence, tillering, flowering, maturation and harvest, respectively.
\end{abstract}

Key words: Triticum aestivum, irrigation, soil water management, tropical climate

\section{Evapotranspiração e coeficientes de cultivo em duas cultivares de trigo irrigado}

RESUMO: No estado do Mato Grosso, a cultura do trigo surge como alternativa ao sistema produtivo atual, principalmente em cultivos irrigados, com novas cultivares melhoradas para este ambiente e sistema. Objetivou-se determinar a evapotranspiração da cultura (ETc) do trigo irrigado e os coeficientes duplos de cultivo de cultivares para o Centro-Oeste brasileiro. O experimento foi realizado no campo utilizando 12 lisímetros e minilisímetros de pesagem, preenchidos por monólitos de solo. Foram utilizadas as cultivares de trigo BRS-254 e BRS-394 no primeiro e segundo ano, respectivamente. A evapotranspiração de referência (ETo) foi obtida pela equação de Penman-Monteith e da cultura por diferença de massa nos lisímetros utilizados para determinar o coeficiente de evaporação de água do solo. Foram determinados os coeficientes basais de cultivo e de evaporação de água do solo conforme os estádios de desenvolvimento da cultura nos dois anos de cultivo. Os valores médios de ETc e ETo foram de 3,87, 3,49 $\mathrm{mm} \mathrm{d}^{-1}$ e de 4,10 e 3,23 $\mathrm{mm} \mathrm{d}^{-1}$, respectivamente, no primeiro e no segundo ciclos de cultivo, com maiores valores de ETc registrados nas fases reprodutivas da cultura, florescimento e enchimento de grãos. Os coeficientes basais de cultivo e os coeficientes de evaporação de água do solo estimados por lisímetros de pesagem preenchidos por monólitos de solo são: Kcb - 0,42, 0,78, 0,94, 0,74 e 0,47 e Ke - 0,72, 0,52, 0,39, 0,58 e 0,13 para a cultivar BRS-254, e $\mathrm{Kcb}-0,28,0,27,0,65,0,98$ e 0,66 e Ke - 1,04, 0,96, 0,65, 0,34 e 0,51 para a cultivar BRS-394, nos estádios de emergência, perfilhamento, florescimento, maturação e colheita, respectivamente.

Palavras-chave: Triticum aestivum, irrigação, manejo de solo e água, clima tropical 


\section{INTRODUCTION}

Wheat (Triticum aestivum) is one of the main cereals used for human consumption. Among the factors that affect its yield, water availability stands out, as the highest yields and improvements in quality are obtained in irrigated crops, promoting a flour of high added value (Borém \& Scheeren, 2015).

In Brazil, the best wheat yields are being obtained in the Midwest region (Borém \& Scheeren, 2015) in irrigated cultivation systems, with flour quality higher than that obtained in the southern region of the country, with predominance of rainfed cultivation, evidencing the potential of central Brazil for self-sustainability in flour production, since the country has a production deficit of about 7 million tons per year (USDA, 2018).

In this context, the state of Mato Grosso, Brazil, has the potential for the production of quality wheat (Guerra et al., 2003). This crop can be used as an alternative for crop rotation and a new economic source for producers, strengthening the social, economic and environmental aspects of the state, which is one of the main agricultural producers in the world.

As the water demand of crops is site-dependent, it is essential to study the evapotranspiration of wheat crop in the state, supporting new studies and being a source of information for government policies and decision making by professionals in the area and rural producers regarding the irrigation management of the crop (Paredes et al., 2014).

In view of the above, the objective of this study was to determine the evapotranspiration of wheat crop under irrigated conditions and the dual crop coefficients of two cultivars for the Brazilian Midwest region.

\section{Material ANd Methods}

The study was carried out in an experimental area belonging to the Instituto de Ciências Agrárias e Tecnológicas of the Universidade Federal de Mato Grosso, Campus of Rondonópolis, Brazil. This area is geographically located at latitude of $16^{\circ} 27^{\prime}$ and longitude of $54^{\circ} 34^{\prime}$, with an altitude of $284 \mathrm{~m}$. The regional climate is tropical (Aw), with dry winter and rainy summer. The mean temperature is $25.1^{\circ} \mathrm{C}$ and the annual rainfall is $1416 \mathrm{~mm}$ (Souza et al., 2013).

There is an agrometeorological station close to the area, from which meteorological data were obtained along the cultivation period. The soil was classified as Oxisol and its chemical analyses were performed according to EMBRAPA (1997) (Table 1).

The area in question has a history of cultivation of two crops and, prior to anthropization, was vegetated by native Cerrado. The field experiment was carried out for two consecutive years (2016 and 2017). The wheat cultivars used in the first and second years of cultivation were BRS-254 and BRS394, respectively, both with medium cycle, high production potential, adapted to the region in question and recommended for cultivation in irrigated system.

The experimental plots consisted of 9 rows spaced by $0.2 \mathrm{~m}$ with length of $6 \mathrm{~m}$. The five central rows, disregarding $0.5 \mathrm{~m}$ on each border, were considered as observation area. In total, nine plots were used.

Crop evapotranspiration was determined by 12 weighing lysimeters and the evaporation of soil water was determined by 12 mini-lysimeters, installed in interrows of the crop, both types in a circular shape, with manual weighing system and filled by soil monoliths collected in the cultivation area. The areas were $706.86 \mathrm{~cm}^{2}$ for the lysimeters and $78.54 \mathrm{~cm}^{2}$ for the mini-lysimeters (Figure 1).

The soil monoliths to fill the lysimeters were collected using a mechanical sampler for soil monoliths of varied shapes and volumes according to Venzon et al. (2018) (Figure 2).

The mini-lysimeters were filled manually, by inserting the tube into moist soil and excavating the sides with an agricultural hoe. After removal, the excess of soil was removed and the assembling process ended with the fixation of a geotextile, to facilitate drainage and avoid soil losses.

The crop coefficients were determined according to the method of the dual Kc, or dual crop coefficient, and the reference evapotranspiration was obtained according to Penman-Monteith FAO-56 equation, Eq. 1 (Allen et al., 1998, 2005).

$$
\mathrm{ET}_{\mathrm{o}}=\frac{0.408 \Delta\left(\mathrm{R}_{\mathrm{n}}-\mathrm{G}\right)+\gamma \frac{900}{\mathrm{~T}+273} \mathrm{u}_{2}\left(\mathrm{e}_{\mathrm{s}}-\mathrm{e}_{\mathrm{a}}\right)}{\Delta+\gamma\left(1+0.34 \mathrm{u}_{2}\right)}
$$

where:

ETo - reference evapotranspiration, $\mathrm{mm} \mathrm{d}^{-1}$;

$\mathrm{Rn}$ - net solar radiation on the surface of the crop, MJ m $\mathrm{m}^{-2} \mathrm{~d}^{-1}$;

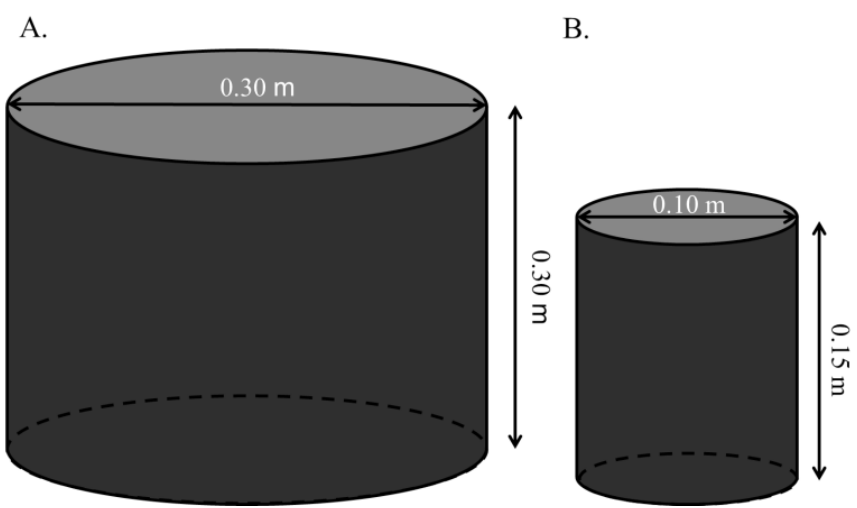

Figure 1. Representation of the dimensions of weighing lysimeters (A) and mini-lysimeters (B) used

Table 1. Chemical characterization of the soil of the experimental area prior to the installation of the experiments in the first and second years of cultivation

\begin{tabular}{|c|c|c|c|c|c|c|c|c|c|c|}
\hline \multirow{2}{*}{ Year } & pH & $P$ & K & $\mathrm{Ca}$ & $\mathrm{Mg}$ & $\mathrm{Al}+\mathrm{H}$ & CEC & \multirow{2}{*}{$\begin{array}{c}\mathrm{OM} \\
\left.(\mathrm{g} \mathrm{kg})^{-1}\right)\end{array}$} & \multirow{2}{*}{\multicolumn{2}{|c|}{ (\%) }} \\
\hline & $\left(\mathrm{CaCl}_{2}\right)$ & & & & & $\left.\mathrm{m}^{-3}\right)$ & & & & \\
\hline $1^{\text {st }}(2016)$ & 5.8 & 7.2 & 84.9 & 3.3 & 1.2 & - & 6.6 & 27.1 & 70.7 & 0 \\
\hline $2^{\text {nd }}(2017)$ & 5.1 & 13.8 & 69.1 & 3.7 & 2.7 & 4.4 & 8.3 & 35.6 & 46.6 & 0 \\
\hline
\end{tabular}


A.

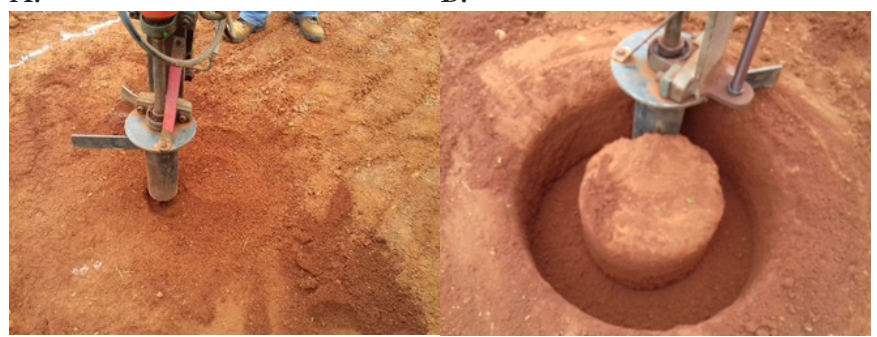

C.

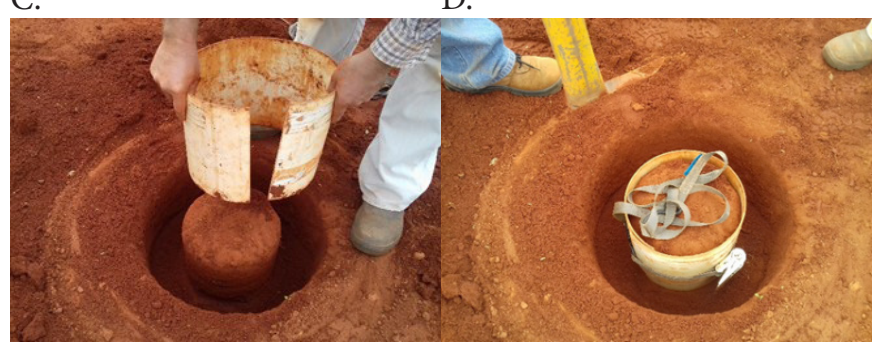

E.

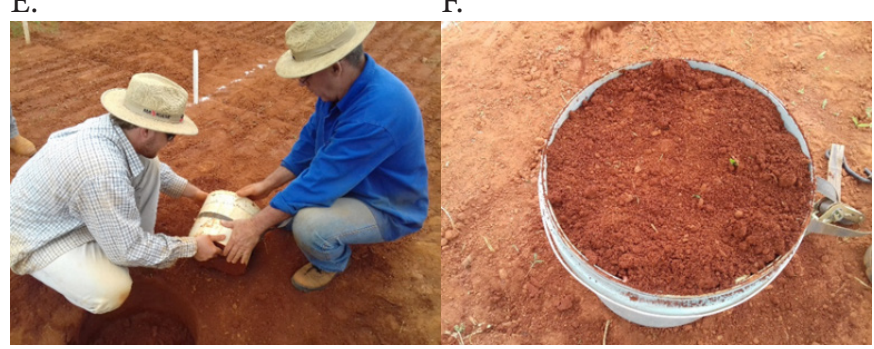

Figure 2. Sequence performed to remove the soil monoliths used. Beginning of excavation and excavated soil monolith (A and $\mathrm{B}$ ), placement of external wall with polyvinyl chloride ring and fastening belt to remove the monolith ( $\mathrm{C}$ and $\mathrm{D})$, monolith removal (E) and filled lysimeter (F)

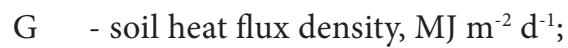

$\mathrm{T}$ - average air temperature at $2 \mathrm{~m}$ height, ${ }^{\circ} \mathrm{C}$;

$\mathrm{u}_{2} \quad$ - wind speed at $2 \mathrm{~m}$ height, $\mathrm{m} \mathrm{s}^{-1}$;

es - saturation vapor pressure, $\mathrm{kPa}$;

$\mathrm{e}_{\mathrm{a}} \quad$ - actual vapor pressure, $\mathrm{kPa}$;

$\mathrm{e}_{\mathrm{s}}-\mathrm{e}_{\mathrm{a}}$ - saturation vapor pressure deficit, $\mathrm{kPa}$;

$\Delta \quad$ - vapor pressure gradient curve, $\mathrm{kPa}^{\circ} \mathrm{C}^{-1}$; and,

$\gamma \quad$ - psychrometric constant, $\mathrm{kPa}^{\circ} \mathrm{C}^{-1}$. Eq. 2.

Crop evapotranspiration was determined according to

$$
\mathrm{ET}_{\mathrm{c}}=\frac{\Delta \mathrm{ML}}{\mathrm{AL}}+\mathrm{P}
$$

where:

ETc - crop evapotranspiration, $\mathrm{mm} \mathrm{d}^{-1 ;}$

$\triangle \mathrm{ML}$ - mass variation in the lysimeter, $\mathrm{kg}$;

$\mathrm{AL}$ - lysimeter area, $0.0674 \mathrm{~m}^{2}$; and,

$\mathrm{P}$ - precipitation, $\mathrm{mm}$.

Soil water evaporation was obtained by dividing the value of the variation in the mini-lysimeter mass by its area, as well as evapotranspiration, by summing the value of precipitation along the period (Flumignan et al., 2012). Ke was obtained by the ratio between soil water evaporation $\left(\mathrm{mm} \mathrm{d}^{-1}\right)$ and ETo. Kcb was determined according to Eq. 3 (Allen et al., 1998).

$$
\mathrm{K}_{\mathrm{cb}}=\frac{\mathrm{ET}_{\mathrm{c}}}{\mathrm{ET}_{\mathrm{o}}}-\mathrm{K}_{\mathrm{e}}
$$

where:

Kcb - basal crop coefficient, dimensionless;

ETc - crop evapotranspiration, $\mathrm{mm} \mathrm{d}^{-1 ;}$

Ke - evaporation coefficient, dimensionless; and,

ETo - reference evapotranspiration, $\mathrm{mm} \mathrm{d}^{-1}$.

The weighing procedures were performed daily at times between 7 and 8 a.m. The data were grouped by means within each stage of wheat crop development (initial - 22, development - 27, flowering - 35 and maturation - 10 days). The values of $\mathrm{Kc}, \mathrm{Kcb}$ and Ke presented in the FAO-56 bulletin (Allen et al., 2005) were considered as standard values for comparison.

Wheat sowing in the area was carried out mechanically, using a SEMINA II experimental plot sowing machine, by distributing about 350 seeds $\mathrm{m}^{-2}$. The management of fertilization, splitting and sources used are presented in Table 2.

The area was irrigated by conventional sprinkler, using a system with an adapted 30-m-wide irrigating bar selfpropelled by a reel system. The irrigation depth was manually measured in each irrigation by rain gauges installed in the area. The water depth to be applied was determined by the sum of reference evapotranspiration (ETo), and the time to perform the irrigation was indicated by soil moisture in the 0-0.20 m layer. Irrigation was performed in the experiment when the moisture content in this layer, which was obtained by a Diviner $2000^{\circ}$ moisture profiling probe (Sentek, 2000), reached the value close to $0.18 \mathrm{~m}^{3} \mathrm{~m}^{-3}$. This value was defined considering an average evapotranspiration of $5 \mathrm{~mm} \mathrm{~d}^{-1}$ with a depletion coefficient of 0.50 , corresponding to the group of annual crops, including wheat crop.

Table 2. Doses, sources and periods of fertilizer application

\begin{tabular}{|c|c|c|c|c|}
\hline \multirow[b]{2}{*}{ Nutrient } & \multirow{2}{*}{$\begin{array}{l}\text { Recommendation } \\
\qquad\left(\mathrm{kg} \mathrm{ha}^{-1}\right)\end{array}$} & \multicolumn{2}{|c|}{ Application splitting (\%) } & \multirow[b]{2}{*}{ Source } \\
\hline & & $\begin{array}{l}\text { Sowing } \\
\text { furrow }\end{array}$ & Top-dressing* & \\
\hline $\mathrm{N}$ & 140 & 30 & 70 & Urea \\
\hline $\mathrm{P}\left(\mathrm{P}_{2} \mathrm{O}_{5}\right)$ & 200 & 100 & - & SSP \\
\hline $\mathrm{K}\left(\mathrm{K}_{2} \mathrm{O}\right)$ & 100 & 100 & - & $\mathrm{KCl}$ \\
\hline Micronutrients & 50 & 100 & - & FTE BR12 \\
\hline
\end{tabular}
in wheat crop

\section{Results AND Discussion}

The basal crop coefficient (Kcb), soil water evaporation coefficient $(\mathrm{Ke})$ and crop coefficient $(\mathrm{Kc})$ along the cycle in both cultivation years can be observed in Figure 3.

It can be observed that, in the initial stage of wheat development, the evaporation coefficient represents most of the evapotranspiration of the crop (about 71\%). As the crop develops, the behavior is reversed, so that the soil cover by the leaves substantially reduces the direct evaporation of soil water and the crop becomes more representative in the evapotranspiration.

The results show the need for a detailed study on evapotranspiration, which will support the definition of 
A.

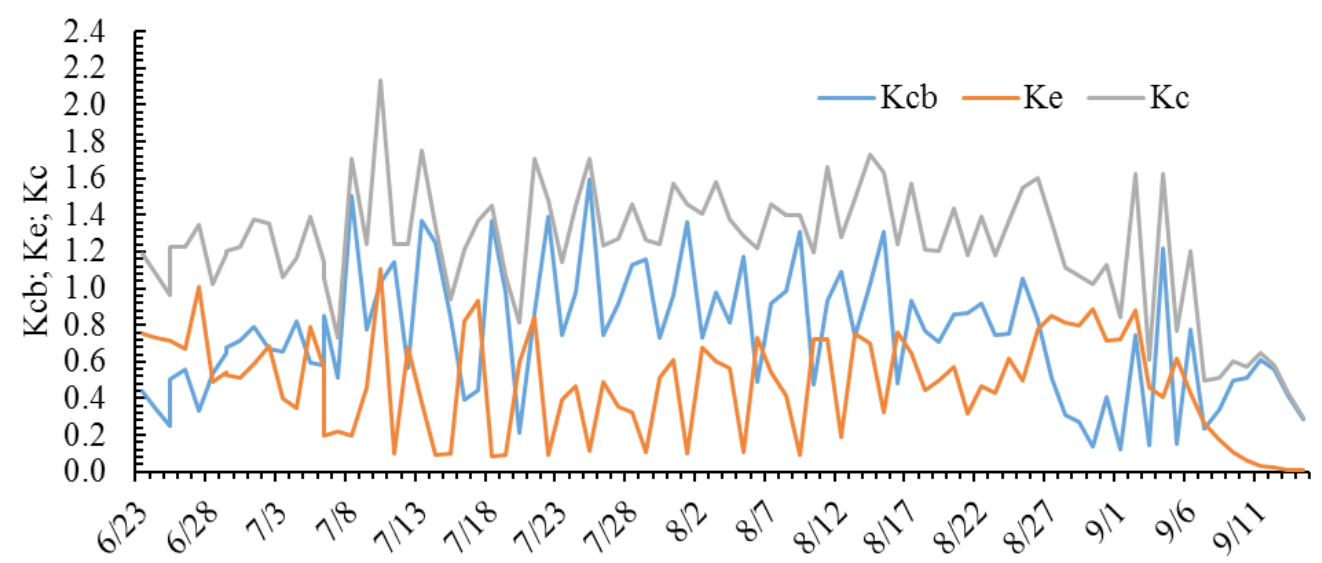

B.

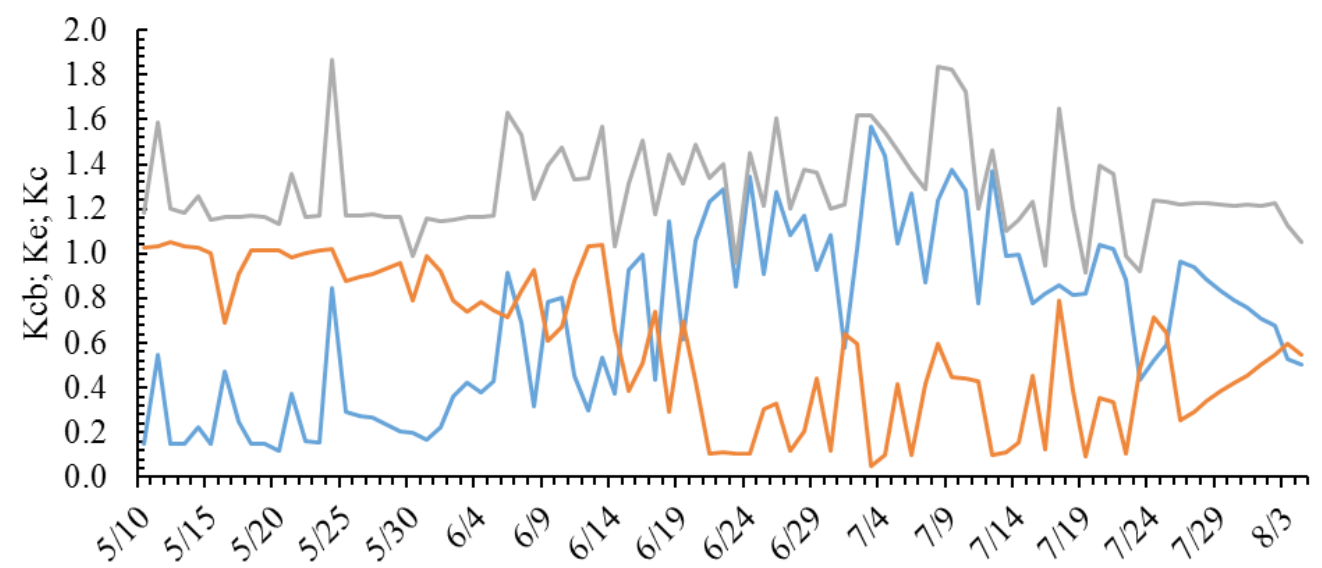

Cultivation period

Figure 3. Basal crop coefficient (Kcb), crop coefficient $(\mathrm{Kc})$ and soil water evaporation coefficient (Ke) for the wheat cultivars BRS-254 (A) and BRS-394 (B) irrigated in a Cerrado region in the state of Mato Grosso, Brazil

management strategies to reduce evaporation losses and the decision-making process regarding agricultural planning. Management is carried out according to the available information, but it is evident that the use of a single crop coefficient results in waste of financial and environmental resources.

Table 3 shows the observed Kcb, Ke, Kc, ETc and ETo of irrigated wheat crop in the Cerrado region of Mato Grosso in both years, according to the stages of development (Large, 1954; Zadocks et al., 1974).

The highest values of Kcb were 0.94 and 0.98 for the first and second years of cultivation, respectively, observed at flowering and maturation of the crop. For Ke, 0.72 in the first year and 1.04 in the second year were the values recorded between emergence and tillering of the crop. Kc, in turn, showed a maximum of 1.33 , representing values above those recommended for the wheat crop (1.10) (Allen et al., 1998).

The mean values of ETc were 3.87 and $4.10 \mathrm{~mm} \mathrm{~d}^{-1}$ and of ETo were 3.49 and $3.23 \mathrm{~mm} \mathrm{~d}^{-1}$, respectively, in the first and second years of cultivation, with higher ETc values recorded in the reproductive stages of the crop, flowering and grain filling.

A study conducted in Northern China with wheat irrigated in winter and corn using the dual Kc method found maximum $\mathrm{Kcb}$ and Ke values close to 1.1 and 1.0 in two years of cultivation (Zhao et al., 2013). Along wheat cultivation, soil water evaporation represented $29 \%$ of ETc. These researchers suggest
Table 3. Basal crop coefficient (Kcb), soil water evaporation coefficient $(\mathrm{Ke})$, crop coefficient $(\mathrm{Kc})$, crop evapotranspiration (ETc) and reference evapotranspiration (ETo) by phenological stage for the irrigated wheat cultivars BRS-254 and BRS-394, cultivated in Oxisol in Cerrado region in the state of Mato Grosso, Brazil

\begin{tabular}{|c|c|c|c|c|c|}
\hline \multirow{2}{*}{$\begin{array}{l}\text { Phenological } \\
\text { stage }\end{array}$} & \multirow{2}{*}{ Kcb } & \multirow{2}{*}{ Ke } & \multirow{2}{*}{ Kc } & ETC & ETO \\
\hline & & & & \multicolumn{2}{|c|}{$\left(\mathrm{mm} \mathrm{d}^{-1}\right)$} \\
\hline & \multicolumn{5}{|c|}{ BRS-254 (First year) } \\
\hline \multicolumn{6}{|l|}{ Sowing } \\
\hline Emergence & 0.42 & 0.72 & 1.13 & 3.80 & 3.36 \\
\hline Tillering & 0.78 & 0.52 & 1.29 & 4.05 & 3.12 \\
\hline Flowering & 0.94 & 0.39 & 1.33 & 4.71 & 3.53 \\
\hline Maturation & 0.74 & 0.58 & 1.32 & 4.46 & 3.30 \\
\hline Harvest & 0.47 & 0.13 & 0.59 & 2.35 & 4.16 \\
\hline Mean & 0.67 & 0.47 & 1.13 & 3.87 & 3.49 \\
\hline & \multicolumn{5}{|c|}{ BRS-394 (Second year) } \\
\hline \multicolumn{6}{|l|}{ Sowing } \\
\hline Emergence & 0.28 & 1.04 & 1.32 & 4.59 & 3.40 \\
\hline Tillering & 0.27 & 0.96 & 1.23 & 3.66 & 2.93 \\
\hline Flowering & 0.65 & 0.65 & 1.30 & 4.17 & 3.21 \\
\hline Maturation & 0.98 & 0.34 & 1.32 & 4.23 & 3.21 \\
\hline Harvest & 0.66 & 0.51 & 1.17 & 3.86 & 3.28 \\
\hline Mean & 0.57 & 0.70 & 1.27 & 4.10 & 3.23 \\
\hline
\end{tabular}

that soil water evaporation data measured in mini-lysimeters should be used with caution because, as there is no removal of water by the roots in the soil of the mini-lysimeter, it may result in overestimation of the water lost by evaporation. 
Researchers evaluating soil water evaporation as a function of different fractions of soil cover by wheat straw, found that evaporation can be reduced by up to $60 \%$ compared to the uncovered soil (Freitas et al., 2014; Mariano et al., 2016).

Yang et al. (2014), evaluating the measurements of evapotranspiration and crop coefficient in wheat cultivated in the winter, found that radiation is the main responsible for the variation in daily values of ETc, and may represent up to $88 \%$ of it. As for the daily variation of crop coefficients, the environmental factors with greatest influence are wind speed, relative air humidity, soil moisture and vapor pressure deficit. The total evapotranspiration of the crop was $252.4 \mathrm{~mm}$.

In Maringá, PR, Brazil, researchers determined the crop coefficient of wheat in weighing lysimeters and soil water evaporation coefficient by mini-lysimeters (Vieira et al., 2016). The values determined were $0.67,0.67,1.01,1.03$ and 0.42 , for the stages of tillering, stem elongation, panicle growth, flowering and maturation, respectively. They also highlighted the need for local studies to determine the crop coefficient under the climatic conditions of development of the crop.

In a study with dual Kc in wheat-corn succession cropping system using the Eddy Covariance method, researchers obtained basal crop coefficients of $0.25,1.15$ and 0.30 for the initial, development and final stages. At the beginning of cultivation, soil water evaporation corresponded to about $80 \%$ of ETc, decreasing to $5 \%$ at the following stages. The mean during the cycle was $28 \%$ for the wheat crop (Zhang et al., 2013).

Several studies have been conducted to determine the crop coefficient of many species in different regions of the planet. Although the dual Kc methodology of the FAO-56 bulletin (Allen et al., 2005) has good accuracy in estimating evapotranspiration and adjustment coefficients for different climatic conditions, genetic improvement and cultivation systems have significantly evolved, justifying the need for regional studies to determine the evapotranspiration of crops under local conditions, since the use of a general coefficient may not represent the local conditions (Pereira et al., 2015).

In this context, in a study for determining the dual crop coefficient for the common bean crop cultivated in Oxisol in Tangará da Serra, Mato Grosso state, Brazil, researchers observed underestimation of Ke in comparison to the standard method (Fenner et al., 2016).

Irrigation interval and cultivation system can influence the increase in soil water evaporation. The highest values of evaporation are recorded when the soil has high moisture content. As it dries, evaporation decreases and will depend on the movement of water in the soil (Philip, 1957; Ponciano et al., 2015).

By analyzing the information generated, it can be observed that there is a need for careful use of these data for planning and decision making. These data can support governmental and private actions regarding the use of water resources in agriculture and technical assistance policies to optimize agricultural production, optimizing areas intended for cultivation and contributing to food security (Ali \& Talukder, 2008).

\section{Conclusion}

The basal crop coefficient and soil water evaporation coefficient estimated by weighing lysimeters composed of soil monoliths are: $\mathrm{Kcb}-0.42,0.78,0.94,0.74$ and 0.47 and Ke- 0.72 , $0.52,0.39,0.58$ and 0.13 for the cultivar BRS-254, and Kcb $0.28,0.27,0.65,0.98$ and 0.66 , and $\mathrm{Ke}-1.04,0.96,0.65,0.34$ and 0.51 for the cultivar BRS-394, at the stages of emergence, tillering, flowering, maturation and harvest, respectively.

\section{Literature Cited}

Ali, M. H.; Talukder, M. S. U. Increasing water productivity in crop production: A synthesis. Agricultural Water Management, v.95, p.1201-1213, 2008. https://doi.org/10.1016/j.agwat.2008.06.008

Allen, R. G.; Pereira, L. S.; Raes, D.; Smith, M. Crop evapotranspiration: Guidelines for computing crop water requirements. Rome: FAO, 1998. 300p.

Allen, R. G.; Pereira, L. S.; Smith, M.; Raes, D.; Wright, J. L. FAO-56 Dual crop coefficient method for estimating evaporation from soil and application extensions. Journal of Irrigation and Drainage Engineering, v.131, p.2-13, 2005. https://doi.org/10.1061/ (ASCE)0733-9437(2005)131:1(2)

Borém, A.; Scheeren, P. L. Trigo: Do plantio à colheita. 1.ed. Viçosa: Editora UFV, 2015. 260p.

EMBRAPA - Empresa Brasileira de Pesquisa Agropecuária. Manual de métodos de análise de solo. 2.ed. Rio de Janeiro: Embrapa Solos, 1997. 212p.

Fenner, W.; Dallacort, R.; Freitas, P. S. L.; Faria Júnior, C. A.; Carvalho, M. A. C.; Bariviera, G. Dual crop coefficient of common bean in Tangará da Serra, Mato Grosso. Revista Brasileira de Engenharia Agricola e Ambiental, v.20, p.455-460, 2016. https://doi. org/10.1590/1807-1929/agriambi.v20n5p455-460

Flumignan, D. L.; Faria, R. T. de; Lena, B. P. Test of a microlysimeter for measurement of soil evaporation. Engenharia Agrícola, v.32, p.80-90, 2012. https://doi.org/10.1590/S0100-69162012000100009

Freitas, P. S. L.; Gava, R.; Faria, R. T.; Rezende, R.; Vieira, P. V. D. Soil evaporation under different straw mulch fractions. African Journal of Agricultural Research, v.9, p.1793-1800, 2014. https:// doi.org/10.5897/AJAR2013.7854

Guerra, A. F.; Rodrigues, G. C.; Rocha, O. C.; Evangelista, W. Necessidade hídrica no cultivo de feijão, trigo, milho e arroz sob irrigação no bioma Cerrado. 1.ed. Brasília: Embrapa Cerrados, 2003. 15p. Boletim de Pesquisa e Desenvolvimento, 100

Large, E. C. Growth stage in cereals: Illustration of the Feekes scale. Plant Pathology, v.3, p.128-129, 1954. https://doi. org/10.1111/j.1365-3059.1954.tb00716.x

Mariano, D. C.; Freitas, P. S. L.; Faria, R. T.; Roberto, R.; Dallacort, R.; Silva, A. L. B. R. Evaporation of soil water based on the quantity and uniformity of crop waste distribuition in soil superfícies. African Journal of Agricultural Research, v.11, p.4762-4734, 2016. https://doi.org/10.5897/AJAR2016.11413

Paredes, P.; Rodrigues, G. C.; Alves, I.; Pereira, L. S. Partitioning evapotranspiration, yield prediction and economic returns of maize under various irrigation management strategies. Agricultural Water Management, v.135, p.27-39, 2014. https:// doi.org/10.1016/j.agwat.2013.12.010 
Pereira, L. S.; Allen, R. G.; Smith, M.; Raes, D. Crop evapotranspiration estimation with FAO56: Past and future. Agricultural Water Management, v.147, p.4-20, 2015. https://doi.org/10.1016/j. agwat.2014.07.031

Philip, J. R. Evaporation, and moisture and heat fields in the soil. Journal of Meteorology, v.14, p.354-366, 1957. https://doi.org/10.1175/15200469(1957)014\%3C0354:EAMAHF\%3E2.0.CO;2

Ponciano, I. M.; Miranda, J. H.; Santos, M. A.; Grah, V. F.; Lier, Q. J. van. An empirical model for predicting soil daily evaporations: Soil and atmospheric variables. Revista Brasileira de Agricultura Irrigada, v.9, p.225-231, 2015.

SENTEK. Diviner 2000: user guide version 1.21. Stepney: Sentek Pty Ltd., 2000.

Souza, A. P.; Mota, L. L.; Zamadei, T.; Martin, C. C.; Almeida, F. T.; Paulino, J. Classificação climática e balanço hídrico climatológico no Estado de Mato Grosso. Nativa, v.1, p.34-43, 2013. https://doi. org/10.14583/2318-7670.v01n01a07

USDA - United States Department of Agriculture. Foreign agricultural service. Available on: <https://apps.fas.usda.gov/psdonline/ circulars/production.pdf $>$. Accessed on November 10, 2018.

Venzon, M.; Bassini, R. T.; Silva, T. J. A.; Bonfim-Silva, E. M. Coletor de amostras de monólitos de solos de volumes variados. BR pat. 202015019059-5 U2, 03 jul. 2018.
Vieira, P. V. D.; Freitas, P. S. L.; Silva, A. L. B. R.; Hashiguti, H. T.; Rezende, R.; Faria Junior, C. A. Determination of wheat crop coefficient $(\mathrm{Kc})$ and soil water evaporation $(\mathrm{Ke})$ in Maringa, $\mathrm{PR}$, Brazil. African Journal of Agricultural Research, v.11, p.45514558, 2016. https://doi.org/10.5897/AJAR2016.11377

Yang, F.; Zhang, Q.; Wang, R.; Zhou, J. Evapotranspiration measurement and crop coefficient estimation over a spring wheat farmland ecosystem in the Loess Plateau. Plos One, v.9, p.1-8, 2014. https://doi.org/10.1371/journal.pone.0100031

Zadocks, J. C.; Chang, T. T.; Konzak, C. F. A decimal code for the growth stages of cereals. Weed Research, v.14, p.415-421, 1974. https://doi.org/10.1111/j.1365-3180.1974.tb01084.x

Zhang, B.; Liu, Y.; Xu, D.; Zhao, N.; Lei, B.; Rosa, R. D.; Paredes, P.; Paço, T. A.; Pereira, L. S. The dual crop coefficient approach to estimate and partitioning evapotranspiration of the winter wheatsummer maize crop sequence in North China Plain. Irrigation Science, v.31, p.1303-1316, 2013. https://doi.org/10.1007/s00271013-0405-1

Zhao, N.; Liu, Y.; Cai, J.; Paredes, P.; Rosa, R. D.; Pereira, L. S. Dual crop coefficient modelling applied to the winter wheat-summer maize crop sequence in North China Plain: Basal crop coefficients and soil evaporation component. Agricultural Water Management, v.117, p.93-105, 2013. https://doi.org/10.1016/j.agwat.2012.11.008 